\title{
53. STABLE-ISOTOPE COMPOSITIONS AND THE ORIGIN OF SECONDARY MINERALS IN ALTERED VOLCANIC ROCKS FROM SOUTHERN HESS RISE, DEEP SEA DRILLING PROJECT SITE $465^{1}$
}

\author{
James R. O'Neil and T. L. Vallier, U.S. Geological Survey, Menlo Park, California
}

\section{INTRODUCTION}

Hess Rise, in the western Pacific Ocean (Fig. 1), formed in the mid-Cretaceous south of the equator and moved north with the Pacific Plate (Lancelot and Larson, 1975; Lancelot, 1978; Vallier et al., 1979). Southern Hess Rise was a volcanic archipelago, at least until late Albian time, after which it subsided to become one of the major aseismic rises in the present western $\mathrm{Pa}$ cific. A second pulse of volcanic activity apparently occurred in the Campanian-Maastrichtian interval, which may be related to tectonic uplift of Hess Rise (Vallier and Jefferson, this volume).

Trachytic rocks underlie 412 meters of carbonate sediments at Site 465 on southern Hess Rise (Fig. 2). Twenty-four meters of trachyte were recovered from a 64-meter cored interval. The rocks are relatively homogeneous in texture, color, and composition, indicating that the cored sequence was probably part of only one magmatic event (Seifert et al., this volume). Large ( $>5-\mathrm{mm}$ ) vesicles and oxidized parts of some flows suggest subaerial or shallow-water extrusions. The rocks are high in silica and relatively rich in $\mathrm{Na}_{2} \mathrm{O}, \mathrm{K}_{2} \mathrm{O}$, and light rare-earth elements.

The upper part of the volcanic-rock sequence is a breccia, the fragments cemented by calcite, pyrite, and rare barite. Some of the resultant veins are more than 1 $\mathrm{cm}$ thick. In addition to the veins, many vesicles are also filled with these minerals. Brecciation and the number and thickness of veins decrease with depth in the hole. The degree of weathering, as indicated by water content, also decreases with depth.

The abundance of the secondary minerals and their megascopic relationships suggest that their origins might be related to hydrothermal activity, and that a thermal event may have affected the flow rocks on southern Hess Rise after extrusion. Such a thermal event might be related to a second phase of volcanic activity, and thereby have some important geologic implications relative to the history of Hess Rise. Determination of stable-isotope ratios in the secondary minerals should provide adequate data for interpreting the origins of the minerals. This paper reports the results of isotopic analyses of sulfur, carbon, oxygen, and hydrogen and their bearing on the source materials and temperatures of secondary mineral formation.

\footnotetext{
'Initial Reports of the Deep Sea Drilling Project, Volume 62.
}

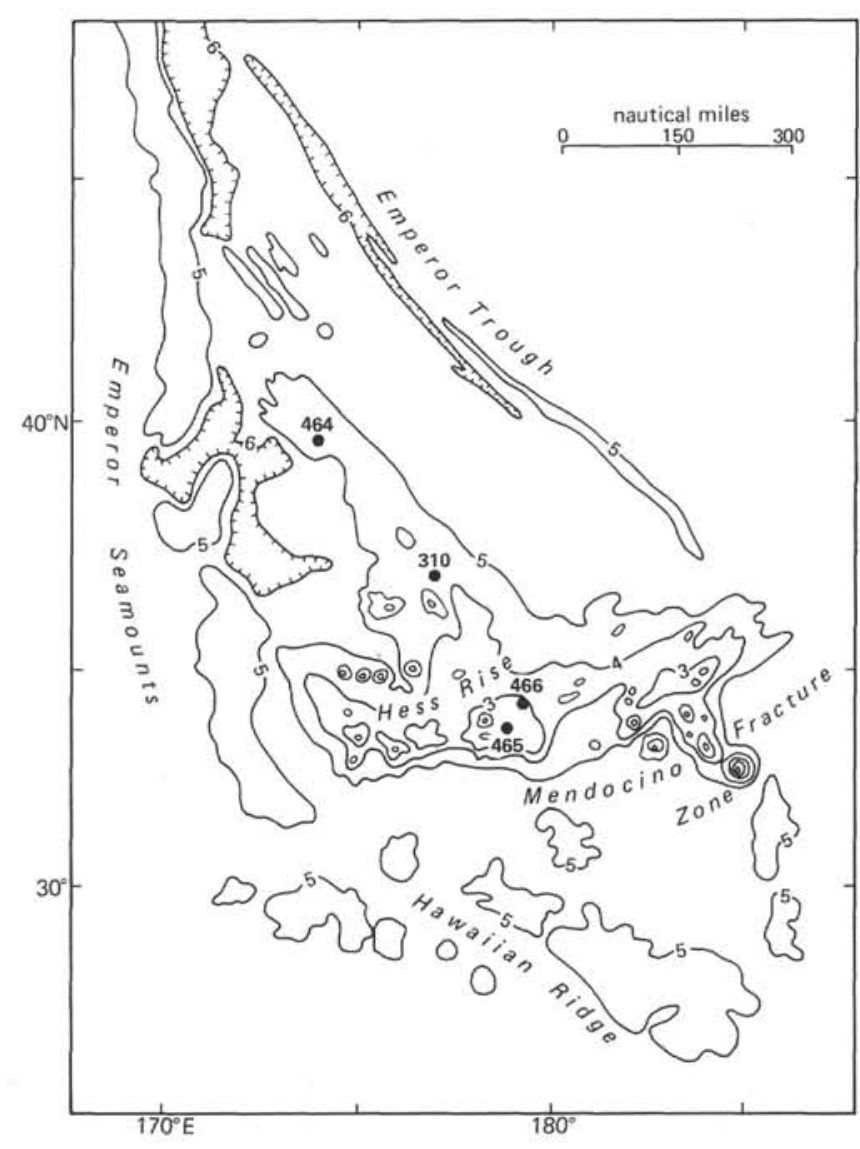

Figure 1. Location map showing sites drilled on Hess Rise. Site 465 is on southern Hess Rise.

\section{METHODS}

Calcite, barite, and pyrite in the rocks from Site 465 are sufficiently coarse-grained that clean separates were easily obtained by hand picking under the binocular microscope. Purity was checked with $\mathrm{X}$-ray diffraction and the petrographic microscope and is more than $98 \%$ in each case. Calcite samples were reacted at $25^{\circ} \mathrm{C}$ with $100 \%$ $\mathrm{H}_{3} \mathrm{PO}_{4}$ (McCrea, 1950), and the liberated $\mathrm{CO}_{2}$ was analyzed for carbon- and oxygen-isotope ratios. Barite was reduced with graphite at $1100^{\circ} \mathrm{C}$, and the liberated $\mathrm{CO}+\mathrm{CO}_{2}$ mixture was converted entirely to $\mathrm{CO}_{2}$ for oxygen-isotope analysis. BaS produced in the reduction reaction was dissolved in warm water and added to $\mathrm{AgNO}_{3}$ solution. The $\mathrm{Ag}_{2} \mathrm{~S}$ precipitate was then reacted with $\mathrm{Cu}_{2} \mathrm{O}$ at $1125^{\circ} \mathrm{C}$ to yield $\mathrm{SO}_{2}$ for sulfur-isotope analysis (Robinson and Kusakabe, 1975). Pyrites were reacted directly with $\mathrm{Cu}_{2} \mathrm{O}$ at $1125^{\circ} \mathrm{C}$ to produce $\mathrm{SO}_{2}$ for isotope analysis. Whole-rock silicate powders were reacted with $\mathrm{BrF}_{5}$ at $650^{\circ} \mathrm{C}$, and the liberated $\mathrm{O}_{2}$ was converted to $\mathrm{CO}_{2}$ for oxygenisotope analysis (Clayton and Mayeda, 1963). For deuterium analysis, the silicates were decomposed at $1400^{\circ} \mathrm{C}$, and the liberated $\mathrm{H}_{2} \mathrm{O}$ was converted to $\mathrm{H}_{2}$ over uranium metal at $800^{\circ} \mathrm{C}$ (Bigeleisen et al., 1952). 


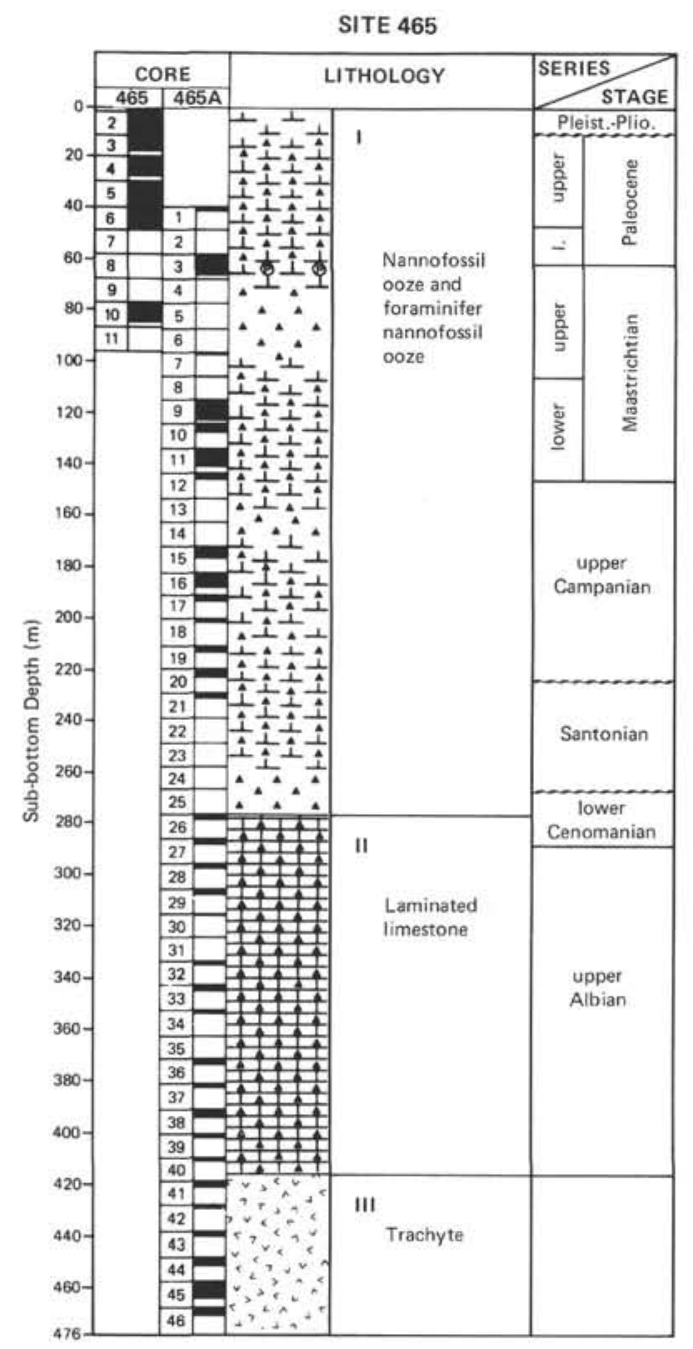

Figure 2. Stratigraphic column for Site 465 . Two holes ( 465 and $465 \mathrm{~A}$ ) and our samples were taken from the trachyte in Hole 465A.

Duplicate analyses were made of all sulfur-isotope compositions, and the oxygen-isotope compositions of the silicates.

Isotopic compositions are given in permil relative to the SMOW $\left({ }^{18} \mathrm{O}\right.$ and D), PDB $\left({ }^{13} \mathrm{C}\right)$, and CDT $\left({ }^{34} \mathrm{~S}\right)$ standards. The analytical errors are $\pm 0.5 \%$ for $\delta \mathrm{D}$ values and $\pm 0.1 \%$ for the other $\delta$ values.

\section{RESULTS AND DISCUSSION}

Samples were selected from the veins and enclosing rocks in the interval 412 to 420 meters (Cores $465 \mathrm{~A}-40$ and $465 \mathrm{~A}-41$ ). Results of the isotopic analyses are given in Table 1.

\section{Sulfur-Isotope Compositions}

The very negative and widely different $\delta^{34} \mathrm{~S}$ values of -38.8 and $-52.1 \%$ for two pyrites sampled very close to one another in the core are characteristic of values that result from relatively low-temperature bacterial reduction of sea-water sulfate $\left(\delta^{34} \mathrm{~S}-20 \%\right)$. Such values have been observed several times (e.g., Krouse et al., 1977; Andrews, 1979). Of greater interest is the unusually high $\delta^{34} \mathrm{~S}$ value of $46.4 \%$ for the single barite sample, which coexists with pyrite that has a $\delta^{34} \mathrm{~S}$ value of $-38.8 \%$. This is among the highest $\delta^{34} \mathrm{~S}$ values ever
Table 1. Stable-isotope analyses of mineral separates and whole-rock powders from altered volcanic rocks of DSDP Hole 465A.

\begin{tabular}{|c|c|c|c|c|c|c|c|c|}
\hline $\begin{array}{c}\text { Sample } \\
\text { (interval in } \mathrm{cm} \text { ) }\end{array}$ & Piece & $\begin{array}{l}\text { Sub-bottom } \\
\text { Depth } \\
\text { (m) }\end{array}$ & Material & $8^{34} \mathrm{~S}$ & ${ }_{{ }^{13}}^{13} \mathrm{C}$ & ${ }_{8}^{18} \mathrm{O}$ & $\delta \mathrm{D}$ & $\underset{(\%)}{\mathrm{H}_{2} \mathrm{O}^{+}}$ \\
\hline $465 \mathrm{~A}-40-2,23-26$ & 7B & 411.2 & Barite & 46.4 & - & 22.6 & - & - \\
\hline $40-2,23-26$ & $7 \mathrm{~B}$ & 411.2 & Pyrite & -38.8 & - & - & - & - \\
\hline $40-2,76-79$ & $7 \mathrm{~B}$ & 411.8 & Pyrite & -52.1 & - & - & - & - \\
\hline $40-2,95-97$ & 5 & 412.0 & Whole rock & - & - & 15.5 & -65 & 1.32 \\
\hline $40-2,129-131$ & $8 \mathrm{~A}$ & 412.3 & Whole rock & $=$ & - & 17.6 & -68 & 1.59 \\
\hline $40-2,129-131$ & $8 \mathrm{~A}$ & 412.3 & Calcite & - & -0.5 & 26.7 & - & - \\
\hline $40-3,5-8$ & IA & 412.6 & Calcite & - & -0.2 & 26.7 & - & - \\
\hline $41-1,5-6$ & 1 & 419.1 & Whole rock & - & - & 16.6 & -62 & 1.92 \\
\hline $41-1,5-6$ & 1 & 419.1 & Whole rock & - & - & 17.6 & -64 & 2.46 \\
\hline $41-1,55-57$ & 5 & 419.6 & Pyrite & -24.6 & - & - & - & - \\
\hline $41-1,83-86$ & $7 \mathrm{~B}$ & 419.8 & Calcite & - & -0.3 & 26.9 & - & - \\
\hline $41-1,83-86$ & iB & 419.8 & Whole rock & $=$ & - & $\begin{array}{l}20.9 \\
13.9\end{array}$ & -71 & 1.47 \\
\hline $41-1,122-124$ & 10 & 420.2 & Whole rock & - & - & 13.9 & -83 & 1.09 \\
\hline $41-1,122-124$ & 10 & 420.2 & Whole rock & - & - & 14.2 & -75 & 1.54 \\
\hline
\end{tabular}

Note: Standards and errors of $\delta$ values are given in the text.

measured for barite, except for certain barite concretions and nodules which presumably formed in isolated "seawater lakes" (Goldberg et al., 1969; Sakai, 1971). The result likely indicates a fairly closed system in which the barite precipitated from a solution enriched in ${ }^{34} \mathrm{~S}$-rich sulfate because of prior precipitation of relatively light pyrite by bacterial reduction.

Alternatively, the production of barite and pyrite could have taken place concurrently, at a rate slow enough (possibly controlled by the rate of sedimentation) that sulfur-isotope equilibrium between the minerals was closely approached. The large ${ }^{34} \mathrm{~S}$ fractionation of $85 \%$ implies a very low temperature of formation for these minerals if it were an equilibrium fractionation. Unfortunately, the equilibrium sulfur-isotope fractionations between barite and pyrite are not known at low temperatures. In any event, these minerals formed at temperatures at which bacteria can exist. The sulfur-isotope data rule out a hydrothermal origin and indicate a sea-water source of sulfur for the pyrite and barite.

\section{Carbon- and Oxygen-Isotope Compositions}

The three samples of calcite have $\delta^{13} \mathrm{C}$ values near zero, effectively proving that they precipitated at low temperature from unaltered sea water. $\delta^{13} \mathrm{C}$ values of marine carbonate sediments are approximately $0 \pm 3 \%$ (e.g., Schwarcz, 1969). Volcanic, organic, and terrestrial sources of carbon have much lower $\delta^{13} \mathrm{C}$ values and have been identified in other materials recovered from deep-sea cores and vesicle fillings in pillow basalts (e.g., O'Neil et al., 1970; Hein et al., 1979).

On the assumption that the calcites precipitated from normal sea water $\left(\delta^{18} \mathrm{O}=0.0 \%{ }_{0}\right)$, their $\delta^{18} \mathrm{O}$ values of $26.7 \%$ indicate a formation temperature of $35^{\circ} \mathrm{C}$, according to the calcite-water expression of O'Neil et al., (1969). Remarkably, the same temperature is calculated from the $\delta^{18} \mathrm{O}$ value of $22.6 \%$ for the barite and the barite-water expression of Kusakabe and Robinson (1977). This is much higher even than the temperature of near-surface waters at the equator today and implies that other factors may have influenced the thermal regime.

Hein and Yeh (this volume) concluded that the temperatures of chert formation in the sediment columns of 
Hess Rise sites were higher than the present in situ temperatures. They further concluded that the greater temperatures probably were not related to increased temperatures of bottom waters during the past, but instead may be related to greater geothermal gradients and (or) to the diagenetic environments.

The temperatures calculated from our data may have the same explanation, but our data certainly are not sufficient for any definite conclusions. A complicating factor here is the uncertainty in the isotopic composition of the pore waters from which these minerals precipitated. Systematic decreases in $\delta^{18} \mathrm{O}$ of pore waters with depth-from 0.1 to $0.5 \% / 100$ meters-have been found in several DSDP cores (Lawrence et al., 1975; Perry et al., 1976). With a maximum decrease of about $2 \%$ in $\delta^{18} \mathrm{O}$ of the pore waters at Site 465 , the calculated isotopic temperatures would be lowered by no more than 8 to $10^{\circ} \mathrm{C}$. Resultant temperatures would be comparable to present surface-water temperatures in the equatorial regions of the world oceans. On the other hand, sea water is slightly enriched in ${ }^{18} \mathrm{O}$ and $\mathrm{D}$ during non-glacial times, and if these conditions prevailed when the secondary minerals were forming, the isotopic temperatures would be several degrees higher.

The $\delta^{18} \mathrm{O}$ values of the whole-rock silicates range from 13.9 to $17.6 \%$ and correlate roughly with water content. $\delta^{18} \mathrm{O}$ values of fresh volcanic rocks are generally about 6.0\% (Taylor, 1968; Muehlenbachs and Clayton, 1972), whereas those of alteration clays and zeolites in ocean-core materials are normally about 18 to 24\% (Savin and Epstein, 1970; Lawrence and Kastner, 1978). Consequently, the observed range of relatively high $\delta^{18} \mathrm{O}$ values merely reflects a varying but marked degree of low-temperature submarine weathering. Savin and Epstein measured high $\delta^{18} \mathrm{O}$ values like these only in marine sediments from equatorial regions.

\section{Hydrogen-Isotope Compositions}

$\delta \mathrm{D}$ values of the whole-rock samples range from -83 to $-62 \%$ and correlate roughly with water contents, as do the $\delta^{18} \mathrm{O}$ values. The dominant hydrogen-bearing mineral is smectite, and $\delta \mathrm{D}$ values like these are typical of low-temperature marine clays (Savin and Epstein, 1970; Yeh and Epstein, 1978). It is noteworthy that the $\delta \mathrm{D}$ values of the three deepest samples are 10 to $20 \%$ lighter than those for samples higher in the column. These same samples have the lowest $\delta^{18} \mathrm{O}$ values as well. It is possible that the alteration of these rocks may have taken place on land by the action of ground waters (depleted in ${ }^{18} \mathrm{O}$ and $\mathrm{D}$ relative to the sea). Another explanation for the rather large difference in $\delta \mathrm{D}$ values (and possibly $\delta^{18} \mathrm{O}$ values) could be that the deeper rocks were altered in a non-glacial period when the sea water was concomitantly lower in deuterium.

\section{SUMMARY}

Veins of secondary pyrite, barite, and calcite occur in altered trachyte flows from Site 465 , on southern Hess Rise. In hand specimen, these minerals appear to be of hydrothermal origin, but stable-isotope analyses indi- cate that they formed at about $35^{\circ} \mathrm{C}$ in the presence of isotopically unaltered sea water. Concordant temperatures were obtained from oxygen-isotope analyses of calcite and barite, assuming a $\delta^{18} \mathrm{O}$ value of zero for the water. This temperature is much higher than those of present equatorial surface waters; therefore, for reasons yet unknown, rock alteration and vein formation took place under a thermal regime which is quite different from those prevailing today.

Pyrite was produced by bacterial reduction of sea water, and a very large ${ }^{34} \mathrm{~S}$ fractionation of $85 \%$ between barite and pyrite suggests a close approach to isotopic equilibrium, which in turn suggests slow formation rates and possibly low sedimentation rates.

$\delta \mathrm{D}$ values of clays vary by over $20 \%$, the lightest samples coming from the deeper parts of the column. Possible explanations include (1) weathering in the presence of ground water when Hess Rise was above sea level, and (2) alteration during times when there was relatively less $\mathrm{D}$ in the ocean.

\section{ACKNOWLEDGMENTS}

The authors thank L. D. White, L. H. Adami, N. Nehring, and W. S. Jefferson for laboratory assistance, and H. W. Yeh and J. R. Hein for helpful discussions.

\section{REFERENCES}

Andrews, A. J., 1979. On the effect of low-temperature seawaterbasalt interaction on the distribution of sulfur in oceanic crust, layer 2. Earth Planet. Sci. Lett., 46:68-80.

Bigeleisen, J., Perlman, M. L., and Prosser, H. C., 1952. Conversion of hydrogenic materials to hydrogen for isotopic analysis. Anal. Chem., 24:1356.

Clayton, R. N., and Mayeda, T., 1963. The use of bromine pentafluoride in the extraction of oxygen from oxides and silicates for isotopic analysis. Geochim. Cosmochim. Acta, 27:43-52.

Goldberg, E. D., Somayajulu, B. L. K., Galloway, J., et al.,1969. Differences between barites of marine and continental origins. Geochim. Cosmochim. Acta, 33:287-289.

Hein, J. R., O'Neil, J. R., and Jones, M. G., 1979. Oxygen of authigenic carbonates in sediment from the deep Bering Sea. Sedimentology, 26:681-705.

Krouse, H. R., Brown, H. M., and Farquharson, R. B., 1977. Sulphur isotope compositions of sulphides and sulphates, DSDP Leg 37. Can. J. Earth Sci., 14:787-793.

Kusakabe, M., and Robinson, B. W., 1977. Oxygen and sulfur isotope equilibria in the $\mathrm{BaSO}_{4}-\mathrm{HSO}_{4}-\mathrm{H}_{2} \mathrm{O}$ system from 110 to $350^{\circ} \mathrm{C}$ and applications. Geochim. Cosmochim. Acta, 41:10331040 .

Lancelot, Y., 1978. Relations entre evolution sedimentaire et tectonique de la plaque Pacifique depuis le Cretace inferieur. Mem. Soc. Geol. France, 134.

Lancelot, Y., and Larson, R. L., 1975. Sedimentary and tectonic evolution of the northwestern Pacific. In Lancelot, Y., Larson, R. L., et al., Init. Repts. DSDP, 32: Washington (U.S. Govt. Printing Office), $925-940$.

Lawrence, J. R., Gieskes, J. M., and Broecker, W. S., 1975. Oxygen isotope and cation composition of DSDP pore waters and the alteration of layer II basalts. Earth Planet. Sci. Lett., 27:1-10.

Lawrence, J. R., Drever, J. J., and Kastner, M., 1978. Low temperature alteration of basalts predominates at DSDP Site 395. In Melson, W. G., Rabinowitz, P. D., et al., Init. Repts. DSDP, 45: Washington (U.S. Govt. Printing Office), 609-612.

McCrea, J. M., 1950. The isotopic chemistry of carbonates and a paleotemperature scale. J. Chem. Phys., 18:849-857.

Muehlenbachs, K., and Clayton, R. N., 1972. Oxygen isotope studies of fresh and weathered submarine basalts. Can. J. Earth Sci., 9:172-184. 
O'Neil, J. R., Clayton, R. N., and Mryeda, T. K., 1969. Oxygen isotope fractionations in diralent metal carbonates. J. Chem. Phys., 51:5547-5558.

O'Neil, J. R., Hedge, C. E., and Jackson, E. D., 1970. Isotopic investigations of xenoliths and host basalts from the Honolulu volcanic series. Earth Planet. Sci. Lett., 8:253-257.

Perry, E. A., Gieskes, J. M., and Lawrence, J. R., 1976. Mg, Ca, and ${ }^{18} \mathrm{O} /{ }^{16} \mathrm{O}$ exchange in the sediment-pore water system, Hole 149 , DSDP. Geochim. Cosmochim. Acta, 40:413-423.

Robinson, B. W., and Kusakabe, M., 1975. Quantitative preparation of sulfur dioxide, for ${ }^{34} \mathrm{~S} /{ }^{32} \mathrm{~S}$ analyses, from sulfides by combustion with cuprous oxide. Anal. Chem., 47:1179.

Sakai, H., 1971. Sulfur and oxygen isotopic study of barite concretions from banks in the Japan Sea off the Northeast Honshu, Japan. Geochem., 5:79-93.
Savin, S. M., and Epstein, S., 1970. The oxygen and hydrogen isotope geochemistry of ocean sediments and shales. Geochim. Cosmochim. Acta, 34:43-63.

Schwarcz, H. P., 1969. The stable isotopes of carbon. Handbook of Geochemistry (Vol. 2/1): New York (Springer-Verlag), 6-B-16-B-15.

Taylor, H. P., Jr., 1968. The oxygen isotope geochemistry of igneous rocks. Contr. Mineral. Petrol., 19:1-71.

Vallier, T. L., Thiede, J., Adelseck, C., et al., 1979. Leg 62 probes the paleo-environments. Geotimes, 24:24.

Yeh, H. W., and Epstein, S., 1978. Hydrogen isotope exchange between clay minerals and seawater. Geochim. Cosmochim. Acta, 42:140-143. 